\title{
Pseudo-Meigs' syndrome due to ovarian metastases from colon cancer: a case report and review of the literature
}

\author{
Atsushi Yamamoto ${ }^{1 *}$, Yoshiaki Miyasaka', Kazushige Furuya', Hideki Watanabe', Masahiro Maruyama', \\ Haruka Nakada', Atsushi Takano', Masao Hada', Hiroshi Nakagomi', Masao Omata² and Toshio Oyama ${ }^{3}$
}

\begin{abstract}
We herein experienced a case with pseudo-Meigs' syndrome that developed both synchronous and metachronous metastases to the ovary from ascending colon cancer. A 57-year-old female visited a hospital for a 2-month history of abdominal distension and voiding difficulty. Massive pleural effusion on the right side and a small amount of left-sided pleural effusion were detected on CT. She underwent emergent laparotomy due to the severe symptom of abdominal distention. The tumor originated from the left ovary, and left-sided oophorectomy was performed. The histologic finding was moderately differentiated adenocarcinoma suggesting metastatic carcinoma from the colon. Left thoracic effusion disappeared at 3 days after the removal of the ovarian tumor. Subsequently, colon carcinoma of the cecum was detected by colonoscopy. The patient underwent second laparotomy of right colectomy and lymph node dissection. However, 6 months after the operation, pleural effusion on the right side re-developed again, and the serum levels of CEA and CA125 were elevated at $105 \mathrm{ng} / \mathrm{ml}$ and $125 \mathrm{U} / \mathrm{ml}$, respectively. CT again revealed a large ovarian tumor. She subsequently underwent third laparotomy of right-sided oophorectomy and hysterectomy. Pleural effusion and ascites disappeared in a few days after the operation.

The patient developed both synchronous and metachronous ovarian metastases and achieved a 7-year disease-free survival after the operation. The pathogenesis of pseudo-Meigs' syndrome should be distinguished from carcinomatous peritonitis and/or pleuritis of malignant disease.
\end{abstract}

Keywords: Pseudo-Meigs' syndrome, Ascending colon cancer, Ovarian metastases

\section{Background}

Meigs and Cass first reported cases that developed nonmalignant ascites and/or pleural effusion in association with benign ovarian tumors such as fibroma, thecoma, and Brenner tumor [1]. These effusions disappeared after the removal of the tumors. Thereafter, this symptom was associated with benign ovarian tumors and referred to as Meigs' syndrome. The same clinical pictures due to a malignant ovarian or pelvic tumor have been referred to as pseudo-Meigs' syndrome [2, 3].

The etiology of Meigs' and pseudo-Meigs' syndrome is not fully elucidated, and no large case series studies are currently available. We herein report a case with

\footnotetext{
* Correspondence: a-yamamoto@ych.pref.yamanashi.jp

${ }^{1}$ Department of Surgery, Yamanashi Prefectural Central Hospital, 1-1-1 Fujimi,

Kofu, Yamanashi 400-8506, Japan

Full list of author information is available at the end of the article
}

pseudo-Meigs' syndrome that developed both synchronous and metachronous metastases to the ovary from ascending colon cancer and review of the pertinent literature.

\section{Case presentation}

A 57-year-old female visited a hospital with a 2-month history of abdominal distension and voiding difficulty. Because of a large pelvic tumor detected on CT, she was referred to the Department of Gynecology at our hospital.

Massive pleural effusion on the right side and a small amount of left-sided pleural effusion were detected on CT (Fig. 1a). Furthermore, CT revealed a large pelvic tumor measuring $13 \mathrm{~cm}$ in diameter (Fig. 1b) and ascites. The cytology of pleural effusion showed no malignant cells. The serum tumor marker levels of CEA, 


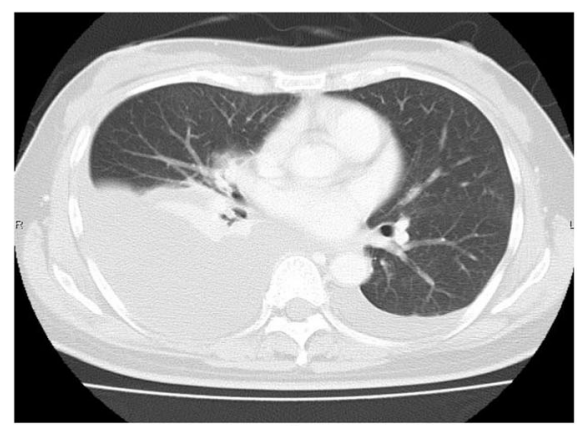

A

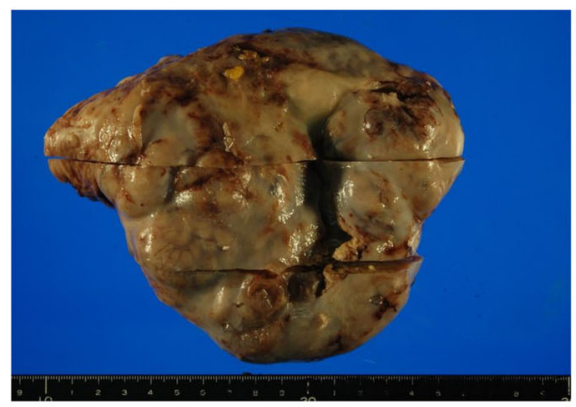

C

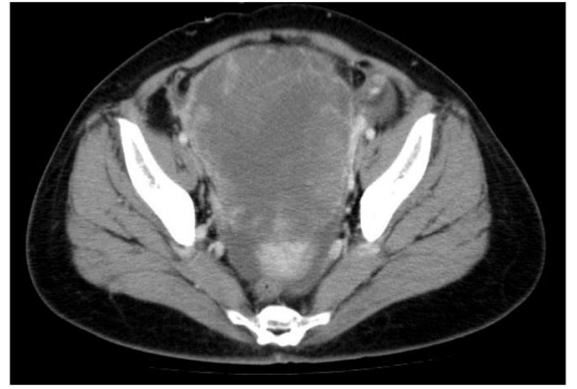

B

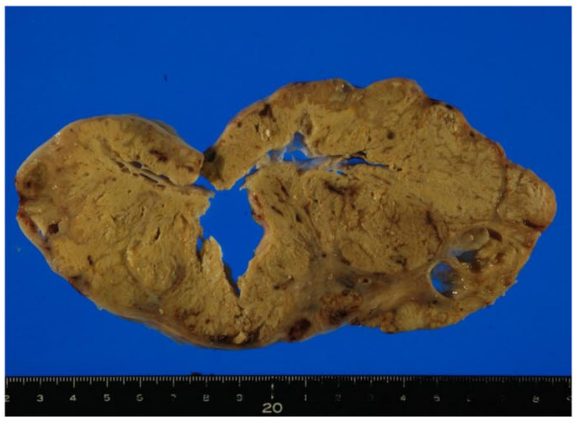

D

Fig. 1 a Chest CT revealed massive pleural effusion at the right side and a small amount of left-side pleural effusion. $\mathbf{b}$ Abdominal CT indicated a large pelvic tumor. $\mathbf{c}$ The tumor of the left-side ovary measured $17 \times 14 \mathrm{~cm}$ and contained necrotic tissues (d)

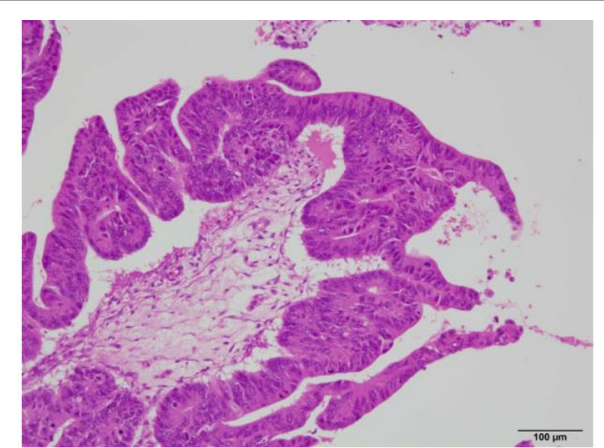

A $\quad H E \quad \times 10$

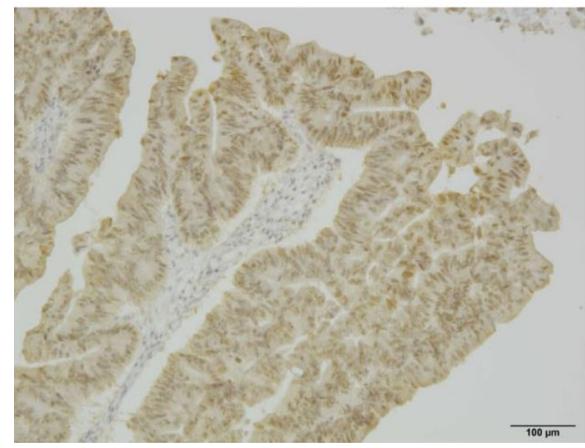

C CDX-2 $\times 10$

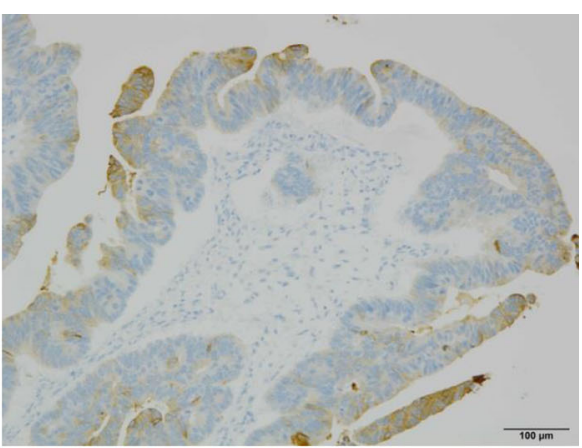

B CK20 $\times 10$

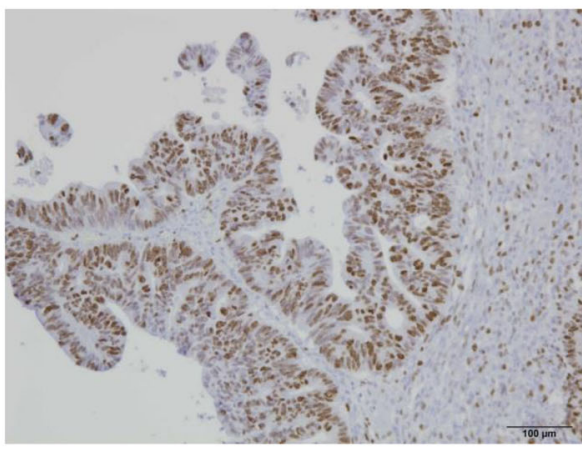

D $\quad$ Ki67 $\times 10$

Fig. 2 a Histologic finding was moderately differentiated adenocarcinoma and CK20 (+) (b) and CDX (+) (c) with immunohistochemistry, suggested metastatic carcinoma from the colon. The Ki67 labeling index of the tumor was very high (>80 \%) (d) 


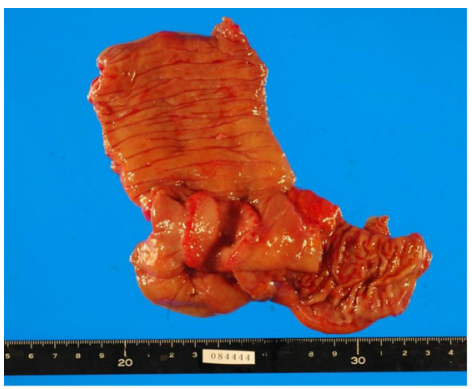

A

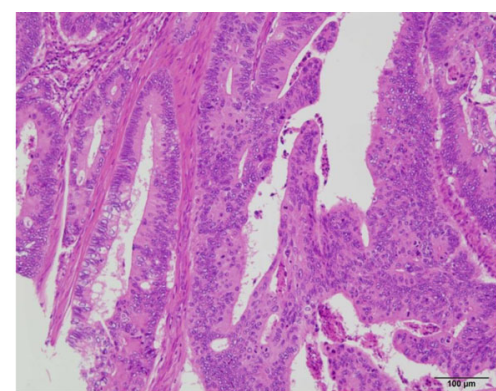

B $H E \times 10$

Fig. 3 a Type 2 colon cancer measuring $4 \times 4.5 \mathrm{~cm}$ was seen. $\mathbf{b}$ Histologic finding indicated mod. ss, ly $(+), v(2+), n+(3 / 33)$

CA19-9, and CA125 were $28.7 \mathrm{ng} / \mathrm{ml}, 60.6 \mathrm{U} / \mathrm{ml}$, and $302 \mathrm{U} / \mathrm{ml}$, respectively. She subsequently underwent emergent laparotomy due to the severe symptom of abdominal distention. The tumor originated from the left ovary, and left-sided oophorectomy was performed. Cytology of ascites showed no malignant cells, and the tumor measured $17 \times 14 \mathrm{~cm}$ (Fig. 1c) and contained necrotic tissue (Fig. 1d). The histologic finding was tubular adenocarcinoma (Fig. 2a), and CK20 and CDX-2 were positive by immunohistochemistry (Fig. 2b c), suggesting metastatic carcinoma from the colon. The Ki67 labeling index of the tumor was also very high ( $>80 \%$ ) (Fig. $2 \mathrm{~d}$ ).

Left thoracic effusion disappeared at 3 days after the removal of the ovarian tumor. Subsequently, we examined the whole body to find the primary tumor site, then colon carcinoma of the cecum was detected by colonoscopy. The patient underwent right colectomy and lymph node dissection again. The operative finding indicated a normal right ovary. The pathologic finding indicated type 2 colon cancer measuring $4 \times 4.5 \mathrm{~cm}$ (Fig. $3 \mathrm{a}$ ), moderately differentiated adenocarcinoma with subserosal invasion, vascular permeation, and lymph node metastases
(3/33) (Fig. 3b). She was treated with oral uracil/tegafur and leucovorin. However, 6 months after the operation, pleural effusion of the right side again developed (Fig. 4a), and the serum levels of CEA and CA125 were elevated at $105 \mathrm{ng} / \mathrm{ml}$ and $125 \mathrm{U} / \mathrm{ml}$, respectively. CT again revealed a large ovarian tumor (Fig. 4b). The patient subsequently underwent right-sided oophorectomy and hysterectomy at 9 months after the left-sided oophorectomy. The tumor on the right-sided ovary measured $21 \times 17 \mathrm{~cm}$ and was histologically confirmed to be metastatic colon cancer, the same as the previous tumor from the left ovary.

Pleural effusion and ascites disappeared in a few days after the operation. She received 9 cycles of FOLFOX-4 chemotherapy (oxaliplatin $80 \mathrm{mg} / \mathrm{m}^{2}$ div at day $1,5-\mathrm{Fu}$ $600 \mathrm{mg} / \mathrm{m}^{2}$, and levofolinate $100 \mathrm{mg} / \mathrm{m}^{2}$ div at days 1 and 2) and has remained alive for 7 years with no recurrence.

\section{Discussion and review of the literature}

Pseudo-Meigs' syndrome is defined as a condition with ascites and pleural effusion that is improved after the removal of an ovarian or pelvic tumor including both

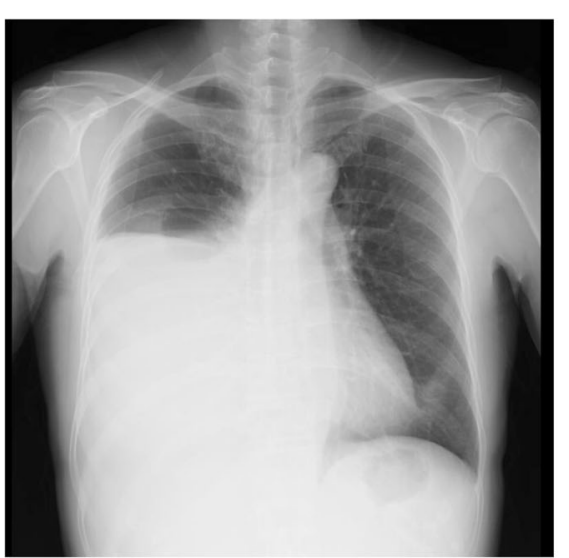

A

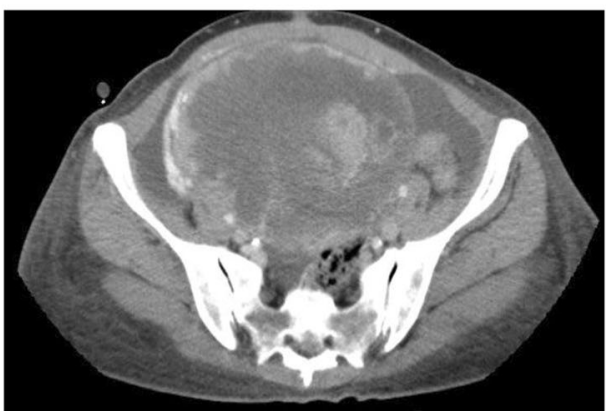

B

Fig. 4 a Six months after the operation, pleural effusion of the right side has developed again. $\mathbf{b}$ CT revealed huge ovarian tumor again 
Table 1 Review of literatures of pseudo-Meigs' syndrome due to ovarian metastases from colon cancer

\begin{tabular}{|c|c|c|c|c|c|c|c|c|c|c|c|c|c|}
\hline \multirow[t]{2}{*}{ Number } & \multirow[t]{2}{*}{ Author } & \multirow[t]{2}{*}{ Year (ref) } & \multirow{2}{*}{$\begin{array}{l}\text { Age } \\
\text { (years) }\end{array}$} & \multicolumn{2}{|c|}{ Colon cancer } & \multirow{2}{*}{$\begin{array}{l}\text { Onset } \\
\text { S or M }\end{array}$} & \multicolumn{2}{|c|}{ Effusions } & \multirow{2}{*}{$\begin{array}{l}\text { Serum CA125 } \\
(\mathrm{U} / \mathrm{ml})\end{array}$} & \multicolumn{3}{|c|}{ Ovarian tumor } & \multirow{2}{*}{$\begin{array}{l}\text { Prognosis } \\
\text { (months) }\end{array}$} \\
\hline & & & & Primary site & Pathology & & Ascites & Pleural & & Site $R$ or $L$ & Size $(\mathrm{cm}) \mathrm{R} / \mathrm{L}$ & Surgical procedures & \\
\hline 1 & Ryan RJ & 1972 [9] & 38 & $\mathrm{~T}$ & nd & $M$ & No & Right & nd & $\mathrm{R}$ & $15 \times 20$ & $\mathrm{BSO}$ & Alive (120) \\
\hline 2 & Tanimura A & 1990 [14] & 40 & D & Well & s & Yes & Bilateral & 1400 & $R / L$ & nd & $\mathrm{BSO}$ & nd \\
\hline 3 & Matsuzaki M & 1992 [15] & 39 & $\mathrm{R}$ & $\bmod$ & S & Yes & Bilateral & nd & $\mathrm{R}$ & $24 \times 22$ & $\mathrm{RO}$ & Alive (12) \\
\hline 4 & Furumoto $T$ & 1993 [16] & 75 & $\mathrm{R}$ & mod & S & Yes & Right & 422 & $R / L$ & $\mathrm{nd} / 21 \times 12$ & $\mathrm{BSO}$ & Alive (12) \\
\hline 5 & Nagakura S & $2000[17]$ & 53 & S & Well & S & Yes & Right & nd & $R / L$ & $18 \times 18 / 12 \times 12$ & BSO ATH & Alive (52) \\
\hline 6 & Koide A & 2002 [18] & 52 & S & Well & S & Yes & Bilateral & 902 & L & $30 \times 25$ & LO & Alive (10) \\
\hline 7 & Inokuma S & 2002 [19] & 42 & RS & mod & S & Yes & Right & 395 & L & $16 \times 9$ & BSO ATH & Alive (42) \\
\hline 8 & Ohsawa T & 2003 [12] & 41 & S & mod & S & Yes & Bilateral & 835 & $R / L$ & $16 \times 12 / 15 \times 13$ & BSO & Died (8) \\
\hline 9 & Hatada T & 2003 [20] & 52 & S & Well & S & Yes & Bilateral & 902 & L & $30 \times 25$ & BSO ATH & Alive (19) \\
\hline 10 & Kobayashi Y & 2003 [21] & 48 & $A$ & Well & S & Yes & Bilateral & 207 & $R / L$ & $14 \times 7 / 15 \times 11$ & BSO ATH & Alive (19) \\
\hline 11 & Feldman ED & 2004 [22] & 49 & C & nd & M & No & Left & 557 & $\mathrm{R}$ & 16 & $\mathrm{BSO}$ & Alive (6) \\
\hline 12 & Shundo $Y$ & 2004 [23] & 43 & S & Well & S & Yes & Right & 81 & $R / L$ & $12 \times 10 / 3 \times 2$ & BSO ATH & Died (24) \\
\hline 13 & Motoyama K & 2005 [24] & 48 & A & mod & S & Yes & Right & 312 & $R / L$ & $4 \times 7 / 21 \times 19$ & BSO ATH & Alive (12) \\
\hline 14 & Sobajima J & 2007 [25] & 54 & S & $\bmod$ & S & Yes & Right & 787 & $R / L$ & $18 \times 12 / \mathrm{nd}$ & $\mathrm{BSO}$ & Died (12) \\
\hline 15 & Ohsawa T & 2007 [26] & 32 & S & Well & S & Yes & Bilateral & 595 & $R / L$ & $17 \times 13 / 3.5 \times 2$ & BSO ATH & Alive (24) \\
\hline 16 & Rubinstein Y & 2009 [27] & 61 & C & nd & S & Yes & Bilateral & 954 & $R / L$ & $\mathrm{nd} / 17$ & $\mathrm{BSO}$ & nd \\
\hline 17 & Ikeda Y & 2009 [28] & 53 & S & $\bmod$ & S & Yes & Bilateral & 618 & $R / L$ & $21 \times 15 / 30 \times 17$ & $\mathrm{BSO}$ & Alive (8) \\
\hline 18 & Miki T & 2010 [29] & 54 & $\mathrm{D}$ & mod & S & Yes & Bilateral & 327 & $\mathrm{R}$ & 18 & $\mathrm{BSO}$ & Alive (14) \\
\hline 19 & Murakami H & 2010 [30] & 45 & S & por & M & Yes & Right & 167 & $R / L$ & $4 \times 2 / 16 \times 12$ & $\mathrm{BSO}$ & Alive (6) \\
\hline 20 & Murakami H & 2010 [31] & 53 & R & Well & M & Yes & Right & 705 & $\mathrm{R}$ & nd & $\mathrm{RO}$ & Died (4) \\
\hline 21 & Ishii M & 2010 [32] & 58 & S & Well & S & Yes & Left & nd & L & $21 \times 20$ & $\mathrm{BSO}$ & Alive (12) \\
\hline 22 & Okuchi Y & 2010 [13] & 43 & $\mathrm{R}$ & mod & M & Yes & Right & 515 & $\mathrm{~L}$ & $11 \times 8$ & $\mathrm{BSO}$ & Died (12) \\
\hline 23 & Komatsu H & 2011 [33] & 49 & A & mod & S & Yes & Right & 67 & $R / L$ & $15 \times 12 / 10 \times 8$ & BSO ATH & Alive (25) \\
\hline 24 & Maeda H & 2011 [34] & 58 & S & Well & S & Yes & Right & 921 & $R / L$ & $15 /$ nd & BSO & Alive (10) \\
\hline 25 & Iwagami Y & 2011 [35] & 36 & S & mod & M & Yes & Right & 427 & $\mathrm{~L}$ & $21 \times 17$ & BSO ATH & Alive (10) \\
\hline 26 & Saito $H$ & 2012 [36] & 44 & S & Well & S & Yes & Bilateral & 576 & $\mathrm{R}$ & $22 \times 22$ & $\mathrm{BSO}$ & nd \\
\hline 27 & linuma A & 2014 [37] & 55 & $A$ & Well & S & Yes & right & 912 & $\mathrm{~L}$ & $19 \times 20$ & LO & Alive (10) \\
\hline 28 & Yachi T & 2015 [38] & 65 & A & Well & M & Yes & Bilateral & 669 & $\mathrm{R}$ & $13 \times 10$ & $\mathrm{RO}$ & Alive (27) \\
\hline 29 & Present case & na & 57 & $A$ & Well & $S, M$ & Yes & Bilateral & 302 & $R / L$ & $17 \times 14 / 21 \times 17$ & LO RO & Alive (89) \\
\hline
\end{tabular}

$C$ cecum, $A$ ascending, $T$ transverse, $D$ descending, $S$ sigmoid, $R S$ recto, sigmoid, $R$ rectum, $S$ synchronous, $M$ metachronous, BSO bilateral salpingo-oophorectomy, ATH abdominal total hysterectomy, $L O$ left oophorectomy, $R O$ right oophorectomy, na not applicable, nd not documented 
benign and malignant ovarian tumors. The primary sites of malignant disease can vary and include an ovarian malignant tumor [4], leiomyoma [5], gastric cancer [6], breast cancer [7, 8], and colorectal cancer [9].

Although the etiology of development of ascites and pleural effusion was not elucidated well, the following explanation has been proposed. Chronic transudation of interstitial edema of a large tumor may cause the persistent retention of ascites [10]. Alternatively, the stromal edema and transudation was caused by an imbalance between arterial and venous blood flow of a large tumor [11]. Furthermore, pleural effusion develops through trans-diaphragmatic lymphatic vessels [12]. Additionally, a correlation with VEGF has been recently suggested [13].

According to a search using the PubMed and Japanese MEDLINE databases (during the period of 1963-2015), 28 cases were reported cases (7 reports published in English and 21 reports published in Japanese with English abstracts). We reviewed the clinical data of the 29 cases, including the present case (Table 1).

The mean age was $49 \pm 9$ years (range 32-65 years), and the primary site of colorectal cancers included the cecum 2 , ascending colon 6 , transversus colon 1 , descending colon 2, sigmoid colon 13 , and rectum 4 patients. The histologic type of colon cancers was well to moderately differentiated adenocarcinoma, except one case which was reported to be poorly differentiated adenocarcinoma.

The onset of pseudo-Meigs' syndrome was $75 \%$ (21/ 28) synchronous and $25 \%(7 / 28)$ metachronous, while a case that developed both synchronous and metachronous, similar to the present case, was not reported.

Nearly all cases had ascites except two cases that developed only pleural effusion. Additionally, all cases had pleural effusions, unilaterally in 16 cases (55\%) (14 on the right side, 2 on the left side) and bilaterally in 13 cases (45\%). The serum level of CA125 was elevated at $557 \pm$ $323 \mathrm{U} / \mathrm{ml}$ (range $67-1400 \mathrm{U} / \mathrm{ml}$ ) in nearly all cases.

Concerning metastatic ovarian tumors, the mean tumor size measured $18 \pm 5 \mathrm{~cm}$ (range $-30 \mathrm{~cm}$ ), and 15 of 29 cases (52\%) had metastatic ovarian carcinoma on both sides, while no laterality was found in unilateral cases. According to these results, bilateral salpingooophorectomy (BSO) should be performed in cases diagnosed with pseudo-Meigs' syndrome. The present case, which demonstrated repeated pseudo-Meigs' syndrome, also emphasizes the necessity of BSO.

The primary clinical challenge for pseudo-Meigs' syndrome is the misdiagnosis with carcinomatous peritonitis or pleuritis. The condition of patients with pseudo-Meigs' syndrome is often confused with terminal stage malignant disease, for which surgical treatment is not indicated except for a palliative surgery. In the previously reported cases, pleural effusions and ascites rapidly recovered after the removal of the ovarian tumors. Moreover, the patients achieved long survivals (Table 1), especially the present patient who achieved a 7-year disease-free survival. According to these findings, the pathophysiology of pseudo-Meigs' syndrome must be distinguished from carcinomatous peritonitis and/or pleuritis of malignant disease. If repeated cytology for effusions is negative for malignant cells, we might have a chance to achieve curative operation.

\section{Conclusions}

We herein reported a case with pseudo-Meigs' syndrome due to ovarian metastases from colon cancer. The patient developed both synchronous and metachronous ovarian metastases and achieved 7-year disease-free survival after the operation. The pathophysiology of pseudo-Meigs' syndrome must be distinguished from carcinomatous peritonitis and/or pleuritis of malignant disease.

\section{Consent}

Written informed consent was obtained from the patient for publication of this case and any accompanying images. A copy of the written consent is available for review by the Editorial-in-Chief of this journal.

\section{Authors' contributions}

$A Y, Y M, H N, M O$, and TO conceived of this case presentation and drafted the manuscript. KF, HW, MM, HN, AT, and MH participated in the treatment of this case. All authors read and approved the final manuscript.

\section{Competing interests}

The authors declare that they have no competing interests.

\section{Author details}

${ }^{1}$ Department of Surgery, Yamanashi Prefectural Central Hospital, 1-1-1 Fujimi, Kofu, Yamanashi 400-8506, Japan. ${ }^{2}$ Department Internal Medicine, Yamanashi Prefectural Central Hospital, 1-1-1 Fujimi, Kofu, Yamanashi 400-8506, Japan.

${ }^{3}$ Department Pathology, Yamanashi Prefectural Central Hospital, 1-1-1 Fujimi, Kofu, Yamanashi 400-8506, Japan.

Received: 12 May 2016 Accepted: 1 August 2016

Published online: 12 October 2016

References

1. Meigs JV. Fibroma of the ovary with ascites and hydrothorax; Meigs' syndrome. Am J Obstet Gynecol. 1954;67:962-85.

2. Maillard E. Meigs and pseudo-Meigs syndrome. Belg Tijdschr Geneesk. 1961:17:788-92.

3. O'Flanagan SJ, Tighe BF, Egan TJ, Delaney PV. Meigs' syndrome and pseudoMeigs' syndrome. J R Soc Med. 1987;80:252-3.

4. Menzin AW. A case of pseudo-Meigs' syndrome secondary to an ovarian germ cell tumor. Gynecol Oncol. 1998;70:441.

5. Dong R, Jin C, Zhang Q, Yang X, Kong B. Cellular leiomyoma with necrosis and mucinous degeneration presenting as pseudo-Meigs' syndrome with elevated CA125. Oncol Rep. 2015;33:3033-7.

6. Horimatsu T, Miyamoto S, Mashimo Y, Okabe H, Mikami Y, Chiba T, et al. Pseudo-Meigs' syndrome caused by a Krukenberg tumour of gastric cancer. Intern Med. 2015;54:2595-7.

7. Fujii M, Okino M, Fujioka K, Yamashita K, Hamano K. Pseudo-Meigs' syndrome caused by breast cancer metastasis to both ovaries. Breast Cancer. 2006;13:344-8

8. Brahmer J, Reckamp KL, Baas P, Crino L, Eberhardt WE, Poddubskaya E, et al. Nivolumab versus docetaxel in advanced squamous-cell non-small-cell lung cancer. N Engl J Med. 2015;373:123-35. 
9. Ryan RJ. PseudoMeigs syndrome. Associated with metastatic cancer of ovary. NY State J Med. 1972;72:727-30.

10. Hopkins M, Malviya VK, Nunez C. Meigs's syndrome and ovarian thecoma in pregnancy. A case report. J Reprod Med. 1986;31:198-202.

11. Samanth KK, Black 3rd WC. Benign ovarian stromal tumors associated with free peritoneal fluid. Am J Obstet Gynecol. 1970;107:538-45.

12. Ohsawa $T$, Ishida H, Nakada H, Inokuma S, Hashimoto D, Kuroda H, et al. Pseudo-Meigs' syndrome caused by ovarian metastasis from colon cancer: report of a case. Surg Today. 2003;33:387-91.

13. Okuchi Y, Nagayama S, Mori Y, Kawamura J, Matsumoto S, Nishimura T, et al. VEGF hypersecretion as a plausible mechanism for pseudo-Meigs' syndrome in advanced colorectal cancer. Jpn J Clin Oncol. 2010;40:476-81.

14. Tanimura A, Tsujisaki M, Yauchi A, Totsugi E, Sawada Y, Iwasaki H, et al. A case of Meigs' syndrome with bilateral ovarian metastasis of the descending colon (in Japanese). Int Med. 1990;66:183-86.

15. Matsuzaki M, Murase M, Kamiya I, Horio S, Sakuma N. A case Meigs' syndrome resulting from rectal cancer (in Japanese). J Jpn Soc Clin Surg. 1992;53:667-70.

16. Furumoto T, Kawamura Y, Mizumoto K, Kishi K, Kato K, Nakamoto S. A case of pseudo Meigs' syndrome caused by bilateral ovarian metastasis from rectal cancer (in Japanese). Geka Sinryo. 1993;35:511-4.

17. Nagakura S, Shirai Y, Hatakeyama K. Pseudo-Meigs' syndrome caused by secondary ovarian tumors from gastrointestinal cancer. Dig Surg. 2000;17:418-19.

18. Koide A, Ookita Y, Inoue Y, Ono T, Tonouchi H, Miki C, Kusunoki M. A case of pseudo-Meigs' syndrome with ovarian metastasis of sigmoid colon cancer. (in Japanese) Mie Igaku. 2002:45:109-13.

19. Inokuma S, Ishida H, Ohsawa T, Sobajima J, Nakamura K, Hashimoto D. Pseudo-Meigs' syndrome caused by ovarian metastasis from rectosigmoid cancer (in Japanese). Nippon Gekarengogakkai Zasshi. 2002;27:793-97.

20. Hatada T, Miki C, Inoue Y, Kobayaashi M, Kusu M. A case of pseudo-Meigs syndrome significantly improved by PMC treatment. (in Japanese) Syuzyutsu. 2003;1:121-12.

21. Kobayashi Y, Toda H, Ooba M, Nakaya Y. A case of Meigs' syndrome from bilateral ovarian metastasis of ascending colon cancer. (in Japanese):Jpn J Gastroenterol Surg. 2003:36:134-38.

22. Feldman E, Hughes M, Stratton P, Schrump D, Alexander H. Pseudo-Meigs' syndrome secondary to isolated colorectal metastasis to ovary: a case report and review of the literature. Gyn Oncol. 2004;93:248-51.

23. Shundo Y, Yokoyama H, Shirakawa M, Hashimoto H, Yoshino G, Kanamaru $\mathrm{H}$. A case of sigmoid colon cancer with Meigs' syndrome. (in Japanese) Nichikyo. 2004:5:500-05.

24. Motoyama K, Ito M, Ando M, Kaneko J, Sekine T, Maejima S. A case of Bilatetal ovarian metastasis of ascending colon cancer presented with pseudo-Meigs' syndrome (in Japanese). Nippon Rinsyogekagakkai Zasshi. 2005;5:1188-93.

25. Sobajima J, Ohsawa T, Okada N, Yokoyama M, Ishibashi K, Ishida H. A case of pseudo-Meigs' syndrome caused by ovarian metastasis from sigmoid colon cancer (in Japanese). Noppon Gekarengogakkai Zasshi. 2007:32(5):778-82.

26. Ohsawa T, Yoshimatu K, Yokomizo, Fujimoto T, Matsumoto A, Ootani T, et al. A case of synchronous ovarian metastasis of sigmoid colon cancer associated with pseudo-Meigs syndrome (in Japanese). Nippon Daichokomonbyogakkai Zasshi. 2007;60(8):480-4.

27. Rubinstein Y, Dashkovsky I, Cozacov C, Hadary A. Pseudo Meigs' syndrome secondary to colorectal adenocarcinoma metastasis to the ovaries. J Clin Oncol. 2009;27:1334-6.

28. Ikeda Y, Kobayashi T, Kamiyama S, Satomoto K, Hagino T, Suemitu I. A case of ovarian metastasis of sigmoid colon cancer with pseudo-Meigs syndrome required urgent surgical treatment. (in Japanese) Shuzyutsu. 2009;63:1199-205.

29. Miki Y, Ikenaga M, Yasui M, Miyazaki M, Mishima H, Tsujinaka T. PseudoMeigs' syndrome caused by ovarian metastasis from descending colon cancer-report of a case. (in Japanese) Jpn J Cancer Clin. 2010;55:41-5.

30. Murakami H, Ogata Y, Fujiyoshi M, Akagi Y, Sasatomi T, Yamaguchi K, Gotanda Y, Shirouzu K. Bilateral ovarian metastasis from sigmoid colon cancer associated with pseudo-Meigs syndrome: a case report (in Japanese). Nippon daichyokomonbyogakkai zasshi. 2010:63:526-30.

31. Murakami H, Ogata Y, Uchida S, Sasatomi T, Yamaguchi K, Yamaguchi R, Shirouzu K. A case of metachronous ovarian metastasis of rectal cancer associated with pseudo-Meigs syndrome. (in Japanese) Nippon Rinshyogekagakkai Zasshi. 2010;71(2):527-32.

32. Ishii M, Ishibashi K, Yokoyama M, Kuwabara K, Ishiguro T, Osawa T, et al. Pseudo-Meigs' syndrome associated with synchronous ovarian metastasis from sigmoid colon cancer: 4 case report (in Japanese). Saitamaken Igakukai Zasshi. 2010:44:443-7.

33. Komatsu H, Nagasaki T, Shibata Y, Yamaguchi H, Nakashima M. A case of pseudo-Meigs' syndrome caused by ovarian metastasis of ascending colon cancer (in Japanese). Nippon Rinshyogekagakkai Zasshi. 2011;72(7):1858-63.

34. Maeda H, Okabayashi T, Hanazaki K, Kobayashi M. Clinical experience of pseudo-Meigs' syndrome due to colon cancer. World Gastroenterol. 2011;17(27):3263-66.

35. Iwagami Y, Mizushima T, Yumiba T, Yamasaki Y. A case of pseudo-Meigs' syndrome caused by metachronous ovarian metastasis from sigmoid colon cancer (in Japanese). Jpn J Gastroenterol Surg. 2011;44:1462-9.

36. Saito H, Koide N, Miyagawa S. Pseudo-Meigs syndrome caused by sigmoid colon cancer metastasis to the ovary. The American Journal of Surgery. 2012;203:e1-3.

37. Inuma A, Asano R, Saito S, Kitayama R, Kagawa A, Nagase H. A case of metastatic ovarian cancer complicated by pseudo-Meigs syndrome. (in Japanese) Kanagawaken Sanfujinkagakkai Zasshi. 2014;50:138-41.

38. Yachi T, Nishikawa S, Tokura T, Iwama M, Akaishi T, Umehara M, et al. A case of pseudo-Meigs syndrome associated with metachronous ovarian metastasis from ascending colon cancer (in Japanese). Jpn J Cancer Chemother. 2015:42:1328-30.

\section{Submit your manuscript to a SpringerOpen ${ }^{\circ}$ journal and benefit from:}

- Convenient online submission

- Rigorous peer review

- Immediate publication on acceptance

- Open access: articles freely available online

- High visibility within the field

- Retaining the copyright to your article

Submit your next manuscript at $>$ springeropen.com 